cific social and cultural contexts. Unlike native speakers, EFL speakers use noun phrases for nomination, predominantly.

Purpose: The purpose of the analysis is to consider the role, which noun phrases play in the English language acquisition by non-native speakers.

Results: According to data obtained from the participants, the noun as an object is the most wide-spread function in the sentence. The subject follows this function and the nouns identified as an adjunct are the least used group. For EFL students, nouns did not represent a nucleus of the sentence, rather, they related it to their syntactic function.

Discussion: the role of nomination is dominant in the English language use. According to the results of studies obtained, descriptive functions of noun phrases, their functionality as language restriction tool were preferred for EFL students.

Keywords: noun phrases, morphological awareness, syntactic function, speech patterns.

Vitae

Nataliia Lazebna is $\mathrm{PhD}$ in Philology, Associate Professor. Her areas of research interests include discourse studies, terminology, computational linguistics, cognitive linguistics, and text linguistics.

Correspondence: natalialazebnaya@gmail.com

Надійшла до редакції 9 грудня 2020 року Рекомендована до друку 23 грудня 2020 року

Олена Олексенко

ORCID: http://orcid.org/0000-0002-6541-8040

DOI 10.31558/1815-3070.2021.41.6

УДК 811.161.2'366:821.161.2'’19'’(092)

\title{
МОРФОЛОГІЧНІ ОДИНИЦІ В ПОЕТИЦІ МИКОЛИ ВІНГРАНОВСЬКОГО
}

У статті розглянуто особливості організачії морфологічних форм у лірищі Миколи Вінграновського як вияв його індивідуальної творчої манери. На рівні морфологічних одиниџь, які беруть участь у поетичному смислотворенні, виявлено поширене в поезї письменника явище співположення спільнокореневих чи однакових слів з елементами авторських новотворів на тісному просторі рядка або строфи. Схарактеризовано випадки морфологічної атракиії й селекиії службових частин мови. Наголошено на необхідності розглядати подібні явища як елементи загальної ідіостильової парадигми поета.

Ключові слова: граматичні засоби, морфологічні одиниці, співположення морфологічних форм, морфологічна атракція, «згущення» морфологічних одиниць, поетика Миколи Вінграновського.

Питання про поетичні смисли, реалізації яких сприяють ті чи ті граматичні форми й значення та особливості їхньої текстової реалізації, «граматика поезії», здавна перебувають у колі наукових зацікавлень лінгвістів (О. Потебня, Л. Булаховський, В. Виноградов, Р. Якобсон, Ю. Лотман та ін.), і увага до цієї теми не послаблюється дотепер (О. Голікова, С. Срмоленко, О. Калашник, Н. Мініна, Л. Синельникова, О. Скоробогатова та багато ін.). Дослідники виходять 3 того, що поетичний текст - це цілісна система і в ньому діє низка особливих закономірностей, одна з яких - закономірність взаємодії одиниць морфологічного рівня в поетичному мовленні як цілісному феномені (Скоробогатова 313). 
Ще Р. Якобсон звернув увагу на те, що поруч із загальноприйнятими прийомами в граматичній фактурі поезії з'являються диференційні риси, типові для словесності певного народу, культури, літературного напряму й для індивідуальності поета чи навіть для окремого твору (Якобсон 471).

Художнє мовлення відомого українського письменника Миколи Вінграновського не раз ставало предметом дослідження лінгвістів: його мовосвіт під різним кутом зору вивчали С. Богдан, Л. Гливінська, Т. Должикова, С. Срмоленко, В. Калашник і Ю. Калашник, Н. Сологуб Л. Старовойт, Л. Стороженко та ін. На роль морфологічних форм у кодифікації мови письменника увага зверталася побіжно, хоча це питання потребує детальнішого окремого дослідження у світлі вивчення української художньої, зокрема поетичної, картини світу, тому тема, обрана для статті, є актуальною.

Отже, об'єкт цієї наукової студії - морфологічний рівень поетичного мовлення Миколи Вінграновського. Предмет - способи актуалізації морфологічних одиниць як чинник творення його особливого мистецького світу.

Мета дослідження - виявити специфіку організації морфологічних форм у ліриці Миколи Вінграновського як ознаку його індивідуальної творчої манери.

Методи і прийоми дослідження: метод прямого лінгвістичного спостереження для встановлення особливостей функціонування морфологічних одиниць у поетичних текстах; інтерпретаційно-текстовий для виявлення поетичних смислів, що пов'язані 3 різними способами актуалізації аналізованих одиниць.

Наукова новизна полягає у виділенні основних способів актуалізації морфологічних одиниць у поетичних текстах Миколи Вінграновського як ознаки його ідіостилю.

Теоретичне значення випливає з розширення уявлення про експресивний потенціал морфологічних форм, дослідження поглиблює знання про поетичні можливості морфологічних одиниць, сприяє розвитку лінгвопоетики.

Практична цінність визначається можливістю використання результатів дослідження в курсі морфології, лінгвістичного аналізу тексту, стилістики, у науковому семінарі з лінгвопоетики і поетичної граматики.

За теоретичне підгрунтя висвітлення зазначеної теми править висловлена й розроблена Р. Якобсоном ідея про «співположення граматичних форм» у поетичних текстах (Якобсон), поглиблена й деталізована в роботах О. Скоробогатової, яка вважає, що «морфологічне співвідношення словесних знаків на невеликому просторі віршованого тексту (у віршованому фрагменті) можна схарактеризувати як співположення, чергування й атракцію, на просторі цілого тексту - як домінанту й граматичний ритм, а на міжтекстовому (гіпертекстовому, макротекстовому) просторі - як поетико-граматичні лейтмотиви» (Скоробогатова 314). Науковиця також стверджує, що «морфологічне співположення в ліричному творі презентоване міжчастиномовним і внутрішньокатегоріальним співположенням» (Skorobogatova 315 ).

Поєднання в тісних межах одного рядка чи однієї строфи або й тексту вірша спільнокореневих слів однієї частини мови чи різних за морфологічним статусом - характерна риса поетики Миколи Вінграновського, на що звертали увагу дослідники його лірики. Зокрема, С. Богдан зазначає, що це улюблений прийом поета, пояснюючи його «міфологічною самодостатністю картини світу, що утверджує свою опору і центр у самій собі» (Богдан 53). Не занурюючись у міфологічні підвалини самосвідомості Миколи Вінграновського, зупиняємося на думці, що схильність поета до тавтологічних зворотів пов'язана 3 фольклорними джерелами його творчого натхнення, що відзначають такі дослідники, як С. Срмоленко (Срмоленко), Л. Фоміна (Фоміна) та ін. Співположення таких форм і частин мови посилюе понятійне значення, закладене в корені слів як семантичному ядрі спільнокореневих утворень: На синю синь води лягла від хмари тінь (На синю синь води лягла від хмари тінь), Зупинилась тиша тиха $і$ незбудна,/ Зупинився в небі вечоровий дим (Зупинилась тиша тиха і незбудна), Але було вже пізно мальвам, / I літові, і ластівкам, / Лиш далечінь синьоблагальна / Когось благала: не пускай!.. (Але було вже пізно мальвам), Щока 
та тінь, та тінні очі, / I ми самі на самоті... (Щока та тінь, та тінні очі), Над гаєм грає птичий грай, / В дощі вдягаються тополі (Над гаєм грає птичий грай), Довго-довго давнє літо давніло, / Де не йшло - стяла синя мла (Довго-довго давнє літо давніло). Такі тавтологічні (плеонастичні) утворення усвідомлено вживаються автором і в читача теж не викликають негативного сприйняття як мовного надміру, оскільки вони наділені високим виражальним статусом, нерідко займають сильну позицію початку вірша, задаючи особливу поетичну тональність, і є візитівкою ідіостилю поета. У цьому сенсі привертає увагу один із віршів Миколи Вінграновського, де на 11 рядків тексту слова із коренем біл- вжито 9 разів: Сестри білять яблуні в саду./ Мати білять хату та у хаті./ Біля хати білий батько на канапі / Вигріває війни та журбу./ Мати білять яблуні в саду./ Мати білять хату та у хаті./ Біля хати білий батько на канапі.../ Мати білять яблуні в саду/ Мати білять хату. Білять хату.. (Сестри білять яблуні в саду). Таке співположення в поєднанні з анафоричним уживанням початку 5 рядків (мати білять) сприяє кінематографічному ефекту - змалювання динамічної картини за дією, вираженою дієсловом білити, виконуваною матір'ю і сестрами, й статичної картини за ознакою білий, презентованою якісним прикметником, що стосується батька, а загалом - ностальгійної картини світлого сімейного спомину.

Творчості Миколи Вінграновського притаманне філософське сприйняття й осмислення життя як руху матерії в часі і просторі, зокрема його невідворотна плинність передається повтором однакових іменників, семантично пов'язаних із часом: За літом літо, літо літо лове, / Чорніє ніч, де вчора день ходив (За літом літо, літо літо лове). Така багаточленність відмінкової парадигми створює ефект накопичення, щільності, певне враження художньої навмисності прийому (Skorobogatova 348). Поліптотон разом із стилістичною фігурою анадиплозису (підхоплення) в цьому разі посилює ефект вербалізації, з одного боку плинності, а 3 другого, - вічності часу. Багатовідмінковість спостерігається також у такому тексті: Цю жінку я люблю. Така моя печаль. / Така моя тривога і турбота. / У страсі скінчив ніч $і$ в cmpaci день почав. / Bid cmpaxy i до cmpaxy ияя любота (Цю жінку я люблю) або ж у такому: Лочиия нюхає туман, / 3 туману пахне їи туманом / I видно: 3-за туману тьмяно / Зіходить місяцьь-молодан (Лошиця нюхає туман). О. Скоробогатова справедливо зазначає, що «в подібних випадках відбувається блокування відмінкових словоформ, значущими є не окремі відмінки і їхні значення, а їхній комплекс. Смисловою єдністю стає багатовідмінковий блок» (Skorobogatova 349). У першому з наведених віршів такий блок передає семантику тривожного відчуття, пов'язаного з можливістю втрати коханої, у другому - стан природи.

Згадана вище поезія «Цю жінку я люблю» насичена також співположними формами дієслова мовчати та віддієслівного іменника мовчання, що репрезентують миттєвості життя у відносній статиці, їхню екзистенційну площину: Що посміхалося - сьогодні у задумі. / I що журилося - не журиться, мовчить./ Мовчить печаль, $і$ сум мовчить у сумі./ I ти мовчиш. Мовчання й те мовчить. Мовчання, тиша - один із провідних концептів Миколи Вінграновського - у цьому разі виявляється за допомогою інтенсивно повторюваних, нагромаджених форм дієслова, їхнього нагнітального переліку, частина з яких метафоризована, що підвищує експресивний тонус поезії - оцінку часу.

Ідіостиль Миколи Вінграновського загалом позначений схильністю автора до накопичення однорідних членів речення, які акумулюють високий рівень текстової змістової емотивності, слугують потужним виявом почуттєвої інтенції поета, що зазначено в роботах дослідників його мовного коду. Однак найбільш виразними виступають ті однорідні члени, які представлені співположними різними частинами мови, що мають однаковий корінь, у наведеному нижче прикладі це іменники й прислівники: Кажуж, кажу ж у звітреному сні / У зимі, в осені, у літі, у весні: / Весною, літом, восени, зимою / Дві білих пісні рук твойх зі мною (Це ти? Це ти. Спасибі... Я журюсь).

Поетичне мовлення Миколи Вінграновського рясніє позанормативними формами слів, серед яких привертає увагу співположення в одному віршовому ряду спільнокореневих слів, частина яких має морфемні чи морфологічні порушення: Обнімає ніч зорю за плечі, / Синьо 
посміхається зоря.../ Ти мені настояна на втечі, / Втеченько-утечо-течія.. (Встав я, - ранній птах). Тут спостерігається ненормативне вживання кличної форми й демінутивного суфікса в іменнику з персоніфікованим абстрактним значенням. Посилює виражальний ефект мовна гра, заснована на вживанні слова течія в одному ряду зі словами втеченька, утеча.

Співположення в тісному тексті строфи спільнокореневих форм іменника і дієслова за умови оказіональності одного й другого маніфестує семантичний акцент на висловленій думці: Наморосило в ній [в Холодній балиі] туманів, / I одинота-одина / У ній одніє й на світанні, / I тільки щастя їй нема... (Заходить сонце. Сніг іде).

Морфологічне співвідношення слів з однаковими чи паронімійними коренями на тісному відрізку однієї строфи, відповідаючи законам єдності віршового ряду, посилює кореневе значення та семантику слова загалом й акцентує ідею поезії, як-от у наведеній нижче строфі, де йдеться про минуле кохання: Воно мені, мабуть, так мало бути. / Мабуть, воно так сказано мені. / Бо так вже склалось - не забуть, не збути, / Не призабути навіть уві сні (Цю жінку я люблю).

Повтор займенників як прийом значної виражальної й семантичної сили - поширене явище в ліриці, на що неодноразово вказували дослідники як на вияв прономінальної скерованості цього жанру літератури. У поетиці Миколи Вінграновського привертають увагу випадки «згущення» на невеликому проміжку тексту різних відмінкових форм займенника, причому 3 порушенням законів сполучуваності, що призводить до значного смислового ефекту: Як ти летіла! Як ти довго билась!/ Мала з малих, крилечечко із крил, / Сама собі сама собою снилась/ До переджнив'я, груш і до могил (Сидів і довго думав над собою).

До таких порушень сполучуваності, що вияскравлюють образи й акцентують смисли, належить і ненормативне використання орудного зі значенням знаряддя дії при дієслові стану: Ти чуєш: плачуть по мені, / Ти чуєш: плачуть за тобою, / У множині і в однині/ Тобою плачуть, плачуть мною (За птахом піниться вода); Сміятись вам, мовчати вами, / Вашим ім'ям сповнять гортань / I тихотихими губами проміння пальчиків гортать... (Сміятись вам, сміятись вами). Виражальний ефект посилюється повтором дієслів плачуть, сміятись.

У «Пісні про життя» наскрізний мотив - оспівування життєвих цінностей ліричного героя, і вербалізація його відбувається в оригінальний спосіб - порушення сполучуваності дієслова заспіваю, яке в своєму активі прямого об'єкта може мати тільки іменники пісню або назви жанрів пісенної творчості (оду, гімн, колядку, щеедрівку, псалом тощо). У вірші ж маємо чотирикратний повтор дієслова заспіваю в поєднанні з твоє ім'я, твою любов, ті імена, тобі себе, у цьому разі знахідний відмінок прямого об'єкта актуалізується, що, безумовно, несе в собі неабиякий виражальний ефект.

Давно помічено, що форми наказового способу відіграють важливу роль у встановленні комунікативних зв'язків зі співбесідником чи читачем, у приверненні їхньої уваги до повідомлюваного чи в заохоченні до якихось дій. У ліриці форми наказового способу слугують інтимізації викладу, їхня художня скерованість виразно прагматична, причому зазвичай вони функціонують як головні члени односкладних речень. Емотивний ефект, пов'язаний із вживанням у тісних межах ліричного твору імперативних форм, зростає в рази, коли спостерігаємо «згущення» таких форм, увиразнене ще й парадигмально - синонімікою відповідних дієслів. Так, у 12 рядках поезії «Поглянь і глянь: 3-за весен зими стали» вжито 12 дієслів у формі 2-ї особи однини наказового способу, причому 6 із них - це форми, утворені від синонімічних дієслів глянути (поглянути) і дивитися, що напряму виражають заклик привернення уваги уявного співрозмовника (у цьому разі - ліричної героїні): Поглянь $i$ глянь: з-за весни зими стали./ Настав той день, я думав - промине./ Осінніми імлистими устами / Не бий, не ріж, не дорізай мене./ Дивись: моря. Дивись: мій погляд - поле. / В легкій руці легке перо ячить, / I степ за полем, щзастя попід болем, / Попід тихеньким болем, щуо мовчить./ Не йди, а глянь. Дивись, пошерхотіли / 3 осінньої нетихої плавби / Очерети. Очерети вчамріли./ Люби мене. Нікого не люби. Ця поезія - експресивно чуттєва, емотивно насичена - багата на співположення інших дієслів (не ріж, не дорізай; люби) й інших частин мови: прикметника легке, 
прийменниково-іменникової конструкції попід болем, іменника очерети, що вкупі створює враження імпульсивно висловленого почуття кохання.

Поетика морфологічних форм і категорій у мовотворчості Миколи Вінграновського тісно пов'язана з морфемно-словотвірними особливостями використаних слів, що мають високий рівень художності й розраховані на значний прагматичний ефект. Зокрема, поет часто вдається до маніпулювання префіксальними утвореннями. Наприклад, це нанизування дієслів доконаного виду з префіксом при-, що має значення наближення до чогось: Прицокало, прибилось, притекло, / Припало, пригорнулось, причинилось, / Заплакало $i$ - никма утекло / Чорняве полум'я з печальними очима і далі: Прицокало, прибилось, прилюбилось...( Прицокало, прибилось, притекло) Інверсований порядок слів у першому реченні вносить певну семантику безособовості (хоча суб'єкт дії - метафоризований образ дівчини чорняве полум'я з печальними очима - наявний), що підтверджується в наступній безособовій конструкції. Дієслова 3 префіксом $n p u$ - виконують у цьому разі смислоцентричну функцію - вибудовують сюжет любовної історії.

Особливо виразними художніми засобами виступають префіксальні оказіональні утворення. Так, префікс пере-, що має значення повторності чи диференціації дії, у Миколи Вінграновського приєднується до дієслів із порушенням валентних морфемних зв'язків, привертаючи таким чином увагу читача до зображуваного: I пересріблюється стан, / Перепоблискують народи (Лошиця нюхає туман). Тут само спостерігаємо й оказіональне творення від дієслова перепочити форми недоконаного виду: Перепочинює ріка.

Микола Вінграновський відомий і своєю майстерністю творити демінутивними і зрідка пейоративними суфіксами нові слова, порушуючи сполучувальний потенціал афіксів. Такі новотвори часто співположні один одному й виступають як єдиний поняттєвий комплекс. Їхнє нагромадження (ампліфікація) є художнім прийомом експресивізації й емотивізації тексту твору: Я крикнув, повен сил і дій: / - Мій світе, світку, світотеньку, / Мій світонько, світище мій!..(Люблю я думать); Коло тебенько я - за всіх. / А як ні-за одне лиш небо.../ Збився з ніг золотий поріг / Біля тебенько, коло тебе (Коло тебенько я - дивись!).

О. Скоробогатова, узявши за основу ідею О. Потебні про структурну єдність і співвідносність усіх елементів мови, що виявляється й у такому понятті, як «атракція форм», розглядає «морфологічну атракцію як прийом, що використовується в художньому (частіше поетичному) мовленні» (Скоробогатова 329). Вона виділяє два типи атракції: перший - як ознака фольклорних текстів або в сучасній поезії як засіб фольклорної стилізації; другий «використання однотипних і симетрично розташованих у віршовому ряду граматичних форм 3 метою створення свого роду граматичної симетрії, яка є однією з основ образної симетрії, що формує асоціативний простір тексту» (Скоробогатова 330).

Дослідники творчості Миколи Вінграновського неодноразово зазначали іiї генетичний зв'язок з фольклорними джерелами - образно-смисловою й символічною палітрою народної пісні, думи, казки. Мовний код письменника, найперше - поета-лірика, відповідним чином відображає цей зв'язок, зокрема й у використанні специфічних народнопісенних конструкцій, які засновані на морфологічній атракції, пов'язаній зі вживанням атрибутивних сполучень 3 прийменниками: У лісі вже нічого не цвіте,/ Цвіте лиш дятел на сосні сумливій / Та синій дзвоник уві млі у мливій, / Це те иввітіння, але вже не те... (У лісі вже нічого не цвіте). Спостерігаємо в цьому разі й вияв співположення різних частин мови з однаковим коренем, що в сукупності з атракцією вимальовує картину природи. Подібні прояви морфологічної атракції в таких рядках: Гоӥв, гоїв, давні гоїв рани, / Як нові димлять вже, наче дим, - / На старі на золоті кайдани / Молоденькі впали кайдани (Що сама тоненька, як бриндуша); Пойхали на Сквиру, на гриби, / На свіже слово, на меди на темні (Поїхали на Сквиру, на гриби). Такий художній прийом, супроводжуваний у тексті повторами спільнокореневих чи однакових слів, посилює образність, структурування й ритмізацію тексту, надає йому виразності й авторської поетичної самобутності. 
Окремої уваги потребують поширені в поетиці Миколи Вінграновського випадки морфологічної селекції службових частин мови, їхнє «згущення» на тісному проміжку віршованого тексту. Н. Мініна й О. Скоробогатова, досліджуючи актуалізацію службових частин мови в поетичному мовленні, зазначають: «Згущення об’єднує окремі значення в більш загальні в одних випадках і перетворює узагальнені граматичні значення на окремішні в інших, що сприяє конкретизації й ускладненню їхньої семантики» (Скоробогатова, Мініна 22). У поезії Миколи Вінграновського спостерігаються випадки накопичення заперечної частки не, що сприяє формуванню заперечних конструкцій як домінант поетичного смислу - передачі загальної ідеї заперечення: Не починайся. Нi з очей, / Hi з губ мені не починайся. / В Холодній Балці сон тече - / Не снись. Не звись. Не називайся (Не починайся. Ні з очей...). Категоричність заперечення посилюється повторюваним єднальним сполучником $\mathrm{Hi}$, повтором однакових і спільнокореневих дієслів та короткими уривчастими реченнями, зокрема останнього рядка, що фіксують традиційну «троїстість» висловлення.

Особливо виразною є художня функція частки не, коли автор усвідомлено акцентує заперечення, зміщуючи наголос на частку, яка стає смисловим центром висловлення, що графічно передається пунктуаційним знаком - тире і крапками: $\boldsymbol{H e}$ - відбувалось. $\boldsymbol{H e}-$ тремтіло. / Не - золотіло. Не - текло. / Не - полотніло. Не - боліло. / Не... - господи!.. - не - не було!.. (Не руш мене. Я сам сумую). Багатократне повторення частки з акцентним зсувом в складі однотипних (безособових) непоширених речень спричинює особливий ритмомелодійний порядок як у вертикальному, так і в горизонтальному напрямку.

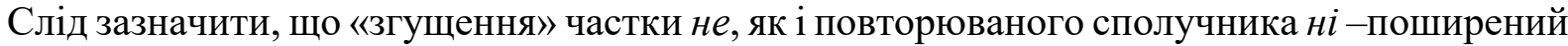
прийом Миколи Вінграновського для нагнітання експресії, вираження гами почуттів у ліричному тексті.

Спричиняють підвищення напруги модальності й повторювані частки щзо то: Що то ніч твоя, щуо то ніч моя, / Що то ти є ти, а то я (Ходить ніч твоя); наче: Наче вони не канни - / Квіти червоноброві, / Наче з моєї крові / Мною загублені рани; / Наче до мене в жили / Прагнуть улитись кров'ю, / Наче вони не дожили / Зненавистю і любов'ю!.. (Канни); частки вже: Вж⿻е хмари омивають мої плечі, / Уже в самому небі я стою, / Уже по груди в небі, вже по пояс, / Вж⿻е Украйну мені видно всю (Ми підійшли до скирти) та ін.

Не менш використовуваний автором і прийом накопичення сполучника $i$, який поєднує речення й однорідні члени, утворюючи стилістичну фігуру полісиндетон. Помічено, що повтор сполучника $i$ сповільнює хід подій, передаваних у вірші, надає їм епічної тональності. На нашу думку, це призводить до кінематографічного ефекту - кадрування сцен життя, їхнє розгортання перед читачем: Летить на берег реактивна щука! / I кумельгом в очах у щуки -ми. / Із ніг на голови, як стій перевертаємось, / I перевернуто бентежимось, $\boldsymbol{i}$ маємось, / I «Волга», й небо, й луки із людьми, /I ичиблина цееркви, і тополі, / I сизі села димарями вниз! / I доля наша... Що ж робити долі, / Коли вже щука хвалить верболіз?.. / Озер осінніх сонні небеса, / I щучі дні, і срібне око шини, / Казан чубатий, хліб і ковбаса / I... Антонінині примружені жоржини (Щуче). Особливо виразною є селекція сполучника в останньому кульмінаційному рядку, який завершує нагнітальний перелік, що підкреслено пунктуаційно - крапками.

Розглянувши поширеність в ліриці Миколи Вінграновського співположення й атракції морфологічних форм як засобів актуалізації граматичних значень у поетичному мовленні, на основі яких створюються поетичні смисли, констатуємо, що до улюблених прийомів поета належить нанизування спільнокореневих і однакових слів, яке часто супроводжується авторськими новотворами, що викликає гру слів, причому спостерігається «ковзання» (термін Р. Якобсона) між співположними граматичними формами, зміна ракурсів означуваного. Співположення відзначаємо не тільки на рівні повнозначних частин мови, а й службових, зокрема часток і сполучників. Менш поширеною, але не менш яскравою є морфологічна атракція за участі прийменників. Такий колорит морфологічних форм і значень $\epsilon$ візитівкою поетичного мовлення Миколи Вінграновського - лірика. 
Граматичні засоби виразності й образотворення не функціонують автономно, їх, безперечно, слід розглядати в парадигмі авторської поетичної картини світу як один із елементів реалізації естетичних уподобань письменника.

Перспективу дослідження вбачаємо в подальшому поглибленому, комплексному вивченні граматичних засобів як системного потенціалу української мови в індивідуальноавторському втіленні.

\section{Література}

Богдан, Світлана. “Специфіка мовних конструкцій у творчості Миколи Вінграновського”. Літературознавство 5, 2010: 52-58.

[Bohdan, Svitlana. "Spetsyfika movnykh konstruktsii u tvorchosti Mykoly Vinhranovskoho". Literaturoznavstvo 5, 2010: 52-58. Print.].

Гливінська, Леся К. “Поезія Миколи Вінграновського: лінгвістичний аналіз”. Українське мовознавство 34, 2005: 50-56.

[Hlyvinska, Lesia. "Poeziia Mykoly Vinhranovskoho: linhvistychnyyi analiz". Ukrainske movoznavstvo 34, 2005: 50-56. Print.].

Єрмоленко, Світлана. “«Слово на долоні мови»”. Культура слова 75, 2011: 6-13.

[Yermolenko, Svitlana. “"Slovo na doloni movy»”. Kultura slova 75, 2011: 6-13. Print.].

Калашник, Володимиһ С., Калашник, Юлія I. "Фразеологія як чинник формування художнього світу поезії і прози Миколи Вінграновського”. Уч. зап. Тавр. нац. ун-ту ім. В. І. Вернадського 6: Філологія. Т. 20 (59), 2007: 173-178.

[Kalashnyk, Volodymyr S., Kalashnyk, Yuliia I. "Frazeolohiia yak chynnyk formuvannia khudozhnoho svitu poezii i prozy Mykoly Vinhranovskoho". Uch. zap. Tavr. nats. un-tu im. V. I. Vernadskoho 6/20 (59), 2007: 173-178. Print.].

Лотман, Юрий М. О поэтах и поэзии. Санкт-Пербург: Искусство, 1996.

[Lotman, Yurij. O poe'tax i poe'zii. Sankt-Peterburg: Iskusstvo, 1996. Print.].

Скоробогатова, Елена А. Грамматические значения и поэтические смыслы: поэтический потенциал русской грамматики (морфологические категории и лексико-грамматические разряды имени). Харьков: НТМТ, 2012.

[Skorobogatova, Elena A. Grammaticheskie znacheniya i poe'ticheskie smysly: poe'ticheskij potencial russkoj grammatiki (morfologicheskie kategorii i leksiko-grammaticheskie razryady imeni). Xar'kov: NTMT, 2012. Print.].

Скоробогатова, Е. А., Минина, Н. С. Грамматические значения и поэтические смыслы: стихотворная актуализация служебных частей речи: моногр. Харьков: ФЛП Бровин А. В., 2017.

[Skorobogatova, Elena, Minina, Nina. Grammaticheskie znacheniya i poe'ticheskie smysly: stixotvornaya aktualizaciya sluzhebnyx chastej rechi: monografiya. Xar'kov: FLP Brovin A. V., 2017. Print.].

Фоміна, Лілія. “Індивідуальний код художньої мови Миколи Вінграновського”. Бахмутський шлях 1-2, 2010: 161-164. URL: 〈http://nbuv.gov.ua/UJRN/bsh_2010_1-2_30> (дата звернення: 25.07.2017).

Fomina, Liliia. "Indyvidualnyi kod khudozhnoi movy Mykoly Vinhranovskoho". Bakhmutskyi shliakh 1-2, 2010: 161-164. <http://nbuv.gov.ua/UJRN/bsh_2010_1-2_30>Web. 25.07.2017.

Якобсон, Роман. "Поэзия грамматики и грамматика поэзии”. [В:] Семиотика: Семиотика языка и литературы. Москва: Радуга, 1983: 462 - 482.

[Yakobson, Roman. "Poe'ziya grammatiki i grammatika poe'zii”. Semiotika: Semiotika yazyka i literatury. Moskva: Raduga, 1983: 462-482. Print.].

\section{Використані джерела}

Вінграновський Микола. Вибрані твори. Київ: Дніпро, 1986.

[Vinhranovskyi, Mykola. Vybrani tvory. Kyiv: Dnipro, 1986. Print.]. 


\section{MORPHOLOGICAL UNITS IN MYKOLA VINGRANOVSKYI'S POETICS \\ Olena Oleksenko}

The Ukrainian Language Department, H. S. Skovoroda Kharkiv National Pedagogical University, Kharkiv, Ukraine

\section{$\underline{\text { Abstract }}$}

Background: Despite of the fact that Mykola Vingranovskyi's artistic speech has been studied multiaspectively, morphological forms, as the factor of his poetics' creation, has not been analysed. However, modern linguistics is paying more and more attention to revealing the laws of interaction of the morphological level units in poetic speech as an integrated phenomenon.

Purpose: to reveal the specificity of the morphological forms organization in Mykola Vingranovskyi's lyrics as the feature of his individual artistic style.

Results: Mykola Vingranovskyi's poetry is characterized by the co-placement of pleonastic patterns, one of which is the author's individual creation - the use of words with the violation of the norms of their combinability, which accentuates the expressed idea. The condensed line of prefixal and suffixal (diminutive) occasional derivatives of the same part of speech appears especially expressive. It is also widespread to accumulate the words with common roots and different casal forms of the same word when the complex of these means becomes meaningful for the poetic sense. The author's poetic individuality finds its realization in morphological attraction - the use of attributive prepositional phrases - and in morphological selection and accumulation of particles, prepositions and conjunctions.

Discustion: Mykola Vingranovskyi's discriminating feature is stringing words with the common root and of the same part of speech accompanied with the author's neologisms. Co-placement is fixed on the level of notional parts of speech and the functional ones. Prepositional morphological attraction is rooted in the folklore and is highly poetic. Morphological means is one of the elements of the language means paradigm that reflect the author's poetic map of the world. The perspective of further research is deeper and multifaceted analysis of grammatical means as systemic potential of the Ukrainian language in individual usage.

Key words: grammatical means, morphological units, co-placement of morphological forms, morphological attraction, accumulation of morphological units, Mykola Vingranovskyi's poetics.

Vitae

Olena, Oleksenko, Candidate of Philology, Professor, Professor of the Ukrainian Language Department, H. S. Skovoroda Kharkiv National Pedagogical University, scientific interests: grammar, derivatology, poetics, stylistics, lexicology, semasiology.

Correspondence: oleksenkoolena@gmail.com

Надійшла до редакції 7 березня 2021 року Рекомендована до друку 21 березня 2021 року 